\title{
The role of SMEs in innovation-oriented economic development
}

\author{
${ }^{1}$ Tamás Köpeczi-Bócz - ${ }^{2}$ Mónika Lőrincz \\ ${ }^{1}$ Corvinus University of Budapest, Budapest, Hungary \\ ${ }^{2}$ University of Miskolc Faculty of Healthcare, Miskolc, Hungary \\ tamas.kopeczi.bocz@uni-corvinus.hu
}

SUMMARY

\begin{abstract}
Both at European and national level tertiary and quaternary sectors are concentrated in the metropolitan centre. In the rural areas only the sites of such sectors can be found the premises of which temporarily transform the sectoral structure of these areas, but from the regional development aspect they did not prove to be an effective strategy.

The European Commission is now focusing on growth from innovation, which could become the driving force behind productivity growth and the economy's long-term trend. The innovation-oriented economic development's key players are on the one hand the knowledge-intensive enterprises, on the other hand the universities. Tertiary education can play a role-among others - in shaping and creating the development of knowledge intensive business environment and conditions, on the other hand it can assist the development of network contacts - another precondition of employment growth.
\end{abstract}

Keywords: university, networking, innovation-oriented economic development, knowledge-intensive business

\section{ÖSSZEFOGLALASS}

A szolgáltatási és az információs szektor a városi területre koncentrálódik mind európai, mind nemzeti szinten. A vidéki területeken szintén léteznek ezek a szektorok, melyek átmenetileg megváltoztatják ugyan a szektorális felépitést, de vidékfejlesztési szempontból nem bizonyultak hatékony stratégiának.

Az Európai Bizottság jelenleg az innovációból fakadó növekedésre fókuszál, mely a termelékenység növelésének motorjává és a gazdaság hosszútávú tendenciájává válhat. Az innovációközpontú gazdasági fejlődés föszereplői egyrészt a tudásintenzív vállalkozások, másfelöl pedig az egyetemek. A felsőoktatás egyebek mellett a tudásintenziv üzleti környezet és körülmények formálásában és fejlesztésében játszhat szerepet, továbbá hozzájárulhat a hálózati kapcsolatok kialakitásához, amely a foglalkoztatottság növelésének elöfeltétele.

Kulcsszavak: egyetem, kapcsolatépités, innovációközpontú gazdasági fejlödés, tudásintenzív vállalkozások

\section{INNOVATION-ORIENTED ECONOMIC DEVELOPMENT DIRECTIVES}

In Central Hungary the structure of economic sectors in the composition and distribution of international trends is more strongly correlated than in the convergence regions - especially the capital city and its surroundings. We can refer to the results of a number of regional research, which also support the idea that in the capital's central region the concentration of tertiary and quaternary sectors can be experienced while in rural areas such sectors can only be met in the sites (Figure 1).

The results of several international research prove that the method of sectoral structure change - in which the traditional sectors as well as subsidiaries of key sectors are relocated from the developed areas into peripheral regions - produce only temporary results, however, in the long run - due to the conservation of the economic structure - it does not prove to be an effective and efficient strategy from the aspect of regional development (Horváth 1994).

Financially strong companies and subsidiaries of multinationals are advancing in the reshaping the mindset more than small and medium-sized enterprises. They transform and plan their business processes and business processes and activities in accordance with the market environment challenges (BPR). A significant number of mostly Hungarian-owned companies can only begin redisigning their business process, when - partly as a result of the global economic crisis - they are in strategic crises situation, which at most promote their survival, but does not help to preserve their market position and competitiveness (Deák 2001).

The domestic and European development policy gives a high priority to economic structure and ability of structural transformation as growth dynamics of strategic service sector has pulled up both domestically and internationally (Figure 2). Partly for this reason, the European Union's cohesion and structural policy is now focusing on innovation oriented economic development, the key players of which are tertiary education institutions. The European Commission puts growth from innovation forward growth from economic restructuring as progress resulting from innovation has no boundaries, and therefore productivity and economic growth can become an important driving force in the long run (European Union 2014).

\section{The criteria for the promotion of innovation}

The basis of innovation-oriented economic development is formed among others by knowledge-intensive enterprises and universities. Knowledge-based enterprises operate in a specific environment with constantly changing sectoral, spatial and temporal dimensions. 
Figure 1: The regional distribution structure of economic sectors in Hungary (2011)

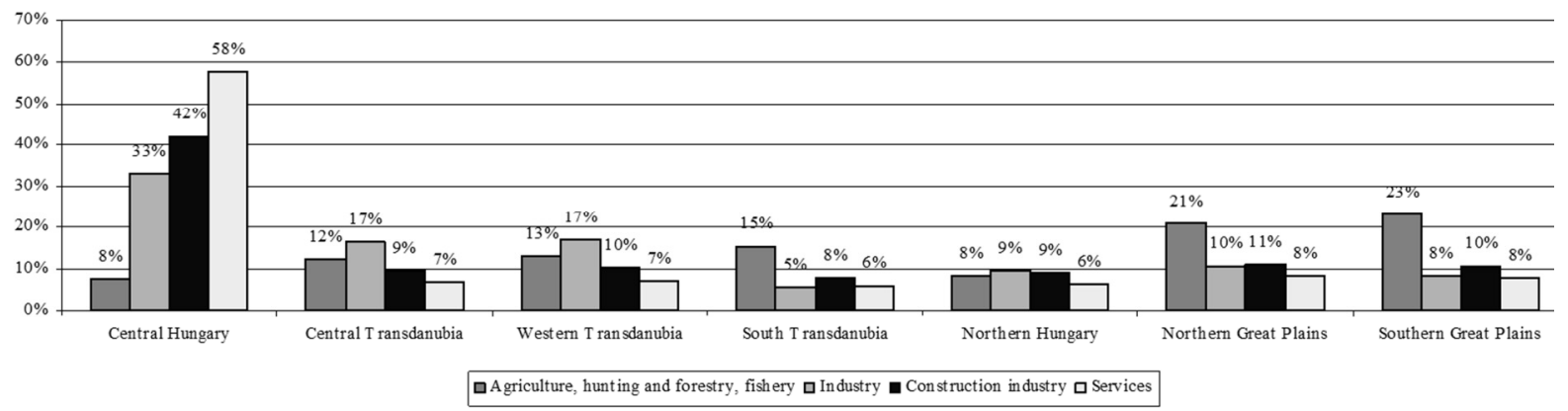

Source: own edition based on CSO data (2012)

Note: proportional to GDP data

Figure 2: Division of structural charasteristics in economic sectors of Hungary (1995-2013)

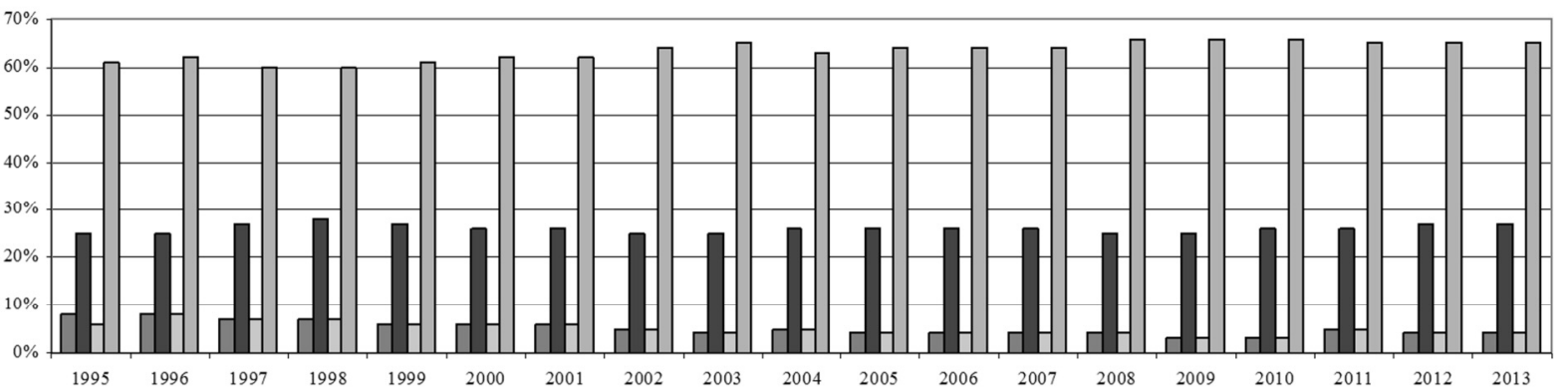

$\square$ Agriculture, forestry, fishery $\square$ Industry $\square$ Construction industry $\square$ Services

Source: own edition based on CSO data (2014)

Note: proportional to GDP data

However these factors are decisive elements of innovation possibilities and indirectly business success (Köpeczi-Bócz and Lőrincz 2016a). These processes can form a strong interdependence between the corporate and academic sectors, in which the role of universities can form the basis of a complex network of relationships (Etzkowitz and Leydesdorff 2000).

A number of domestic research results also confirmed that the intensity of the company's deep university relationships significantly affect the innovation activities of small and medium-sized enterprises. The number of business in rural regions - due to more moderate activity for innovation - hardly supported demand for university research and development towards a substantial innovation performance. For this reason the innovation transfer of universities requires an increasing community involvement as - due to the disadvantageous situation of local economy - R\&D\&I cooperation of universities and companies is facing difficulties. Regional performance depends to a large extent on the development of the public financing system of R\&D\&I which can give rise to the greater proportion of companies to benefit from the different aid forms. In encouraging R\&D\&I activity public financing and community envolvement can offset the lack of private funding (European Union 2014, Gál 2014).

Based on the innovative activity of SME's and competency levels, OECD, the company distinguishes four levels of company types. The first level refers to the static companies that tipically rarely generate innovations, but in the existing conditions their market positions are considered stable. On the second level there are innovative companies that are able to manage innovation processes in a stable competitive and technological environment. A company on the third level differs from that of the second level that it has a potential to adapt the changing environmental conditions. Finally, re-organised company type on the fourth level - using its own technology - is capable of repositioning itself on the market and has competencies to create new markets as well (OECD 2004). The European Commission approaches the different dimensions of competitiveness at regional level and differentiates regional development and growth promoting components with the help of (RCI). In referring to the highest level of development technological readiness, business development and innovation are the key components (European Union 2014).

THE ROLE OF NETWORKING IN THE GROWTH OF INNOVATIVE ENTERPRISES

The spatial distribution of knowledge-intensive enterprises and service providers is uneven on both domestic and European level typically concentrated in core regions. It has been in the focus of several researchers whether the interactions of knowledgeintensive businesses and services are limited in space. 
The institutional framework and potential as well as connection network of economic operators have site specific addictions and determinism, similarly, the innovative companies and the related service providers wear specific features in the respect of territorial ambient conditions (Lörincz and Köpeczi-Bócz 2016a).

The results of empiric studies in Denmark showed that for companies operating in the peripheral regions intense interactions - measured by the proportion of employees - led more likely to an increase in core areas such as (Drejer and Vindig 2005). The results of empirical surveys in Germany, however, showed that the geographic proximity has a bigger role in the case when production knowledge providers provide business (Muller 2001). In Hungary in the tertiary sector high value-added knowledge-intensive enterprises are concentrated mainly in the capital. Due to the central position of Budapest possibilities of co-operation and integration have always been broader than in rural areas. The sector concentration leads to a paradoxical situation in the respect that the specialized university $\mathrm{R} \& \mathrm{D}$ and innovation performance - as service providers - are in the convergence region.

\section{The role of the resources of the knowledge-intensive business networking relations}

Several studies have pointed out that the innovation potential of small and medium-sized enterprises face in almost all cases the various constraints in their developmenr, For this reason, the development of networking often aims at loosening or degradation resource constraints. The literature also separates resource-based networks as „stand-alone” types (Ford 2003). The characteristics of the network connections are determined by a number of closely interacting factors that are associated with motivation as well. The networks evolve along multiple bond. For bonds based on the business relationship the main motivating factor is what types of activities the network members are linked in cooperation. In case of research cooperation the bond of shared resources dominates the formation and development of relations (Häkansson and Snehota 1995, Bajmóczy et al. 2010).

The biggest problem - and dam - of the operation and development of small- and medium-sized companies is the difficult access to resources and the lack of nonmarket based mediation (Kállay 2000, Köpeczi-Bócz and Lörincz 2016a). The availability of sources of funding, regulatory environment, access to resources as well as willingness to cooperate and culture are the keystone of not only the creation of networking, but also the formation of a recipient economic environment and conditions, which can catalyze and stimulate economic growth and development at micro and macro level alike (Lőrincz and Köpeczi-Bócz 2016b.).

The former empirical investigation on R\&D\&I criteria to assess university and company aspects ${ }^{1}$ showed that the sectoral nature of knowledge-intensive businesses, the specific attributes of their operation, their innovation process, life-cycle induce different needs. These features also differentiate in time when and what type of resources they require for their activity. As for the availability of capacity do the companies co-benefit from the cooperation which enables them to have an access to resources which they do not own individually to reach their goal.

Innovative small and medium-sized enterprises' $R \& D$ and innovation activities infer the nature and main orientation for the development of networks of cooperation, as industrial relations in the industrially limited companies also suggest, what other workflows, sectors, progression they need and how the various phases of production plant can be connected this way. The displacement of structural proportion of the regional branch - on medium and long term - may affect the relationship between the nature of the production chain (Szerb 2003, Köpeczi-Bócz and Lörincz 2016b).

\section{THE IMPACT OF EUROPEAN UNION COHESION AND STRUCUTRAL POLICY TRANSFORMATION OF THE RELATIONSHIP NETWORKS}

The R\&D\&I system of conditions and corporate aspects of the university's assessment of the involvement of business primarily targeted innovative companies based in the Northern Hungarian region, which may have been relevant in terms of the results obtained during the evaluation (Figure 3). A further objective was to address enterprises beyond the borders of the region in order to find out whether their geographical distance or the geographical position influence and motivate their willingness to cooperate.

\section{Figure 3: The type of respondent firms}

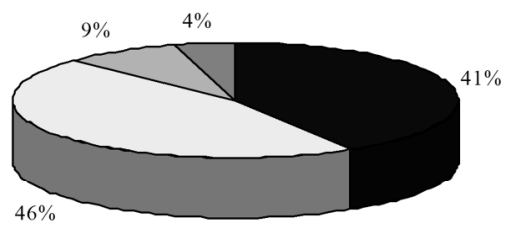

Micro-enterprises $\square$ Small business $\square$ Medium-sized businesses $\square$ Big business

Source: based on the questionnaires edited

Although it was not significant in the survey sample, but still remarkable that companies based in the central region would willingly cooperate - especially in joint R\&D\&I projects - with rural universities, however they do not know how and in what form could a rural university in the convergence region and a company with its headquarters in Budapest implement a common R\&D\&I project - because of the criteria of application support. This proposition suggests that firms in Central

${ }^{1}$ Connected to the research questionnaire "at the University of Miskolc and Miskolc coordinated knowledge transfer and innovation services development and deployment of sustainable strategic partnership with actors of the" framework was made, TÁMOP-4.2.1.C-14/1/KONV2015-0012 project identification number. 
Hungary capable of developing have growth potential, but due to their geographical location they do not have an access to development resources (Figure 4).

Figure 4: Designed by the businesses development scale

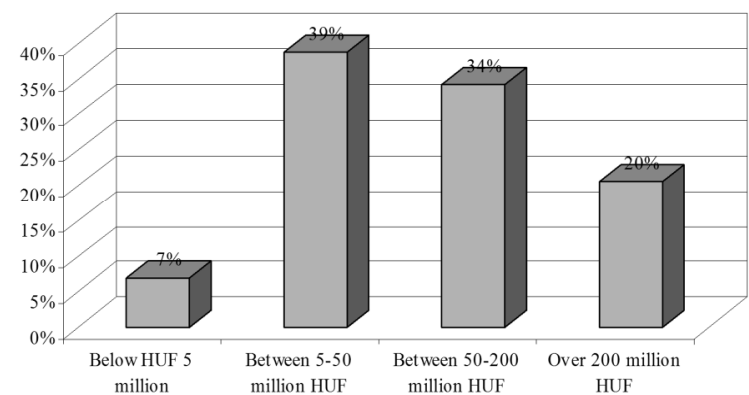

Source: based on the questionnaires edited
The prerequisite of job creation is a developing dynamic business environment (Table 1) (KöpecziBócz 2000). Their willingness to cooperate in this case is not motivated by geographical distance, but their geographical location. They are also looking for the ways to have an access to resources (development funds) (Figure 5). To bridge the problems caused by the criteria of competition may result in new types of co-operation. Such development of the existing forms can lead to new types of networking and the appearance of indirect effects of the central region. However, it should be noted that the core question of regional businesses is in some respects inconsistent with the EU's structural and cohesion policy which are usually not considered core areas of intervention.

Table 1.

The number of employees by economic sectors (2014)

\begin{tabular}{lcccc}
\hline \multicolumn{1}{c}{ Region } & Agriculture & Industry & Services & In total \\
\hline Central Hungary & 12 & 283 & 1014 & 1310 \\
Central Transdanubia & 22 & 193 & 252 & 468 \\
Western Transdanubia & 19 & 175 & 248 & 443 \\
South Transdanubia & 29 & 107 & 220 & 359 \\
Northern Hungary & 16 & 152 & 260 & 344 \\
Northern Great Plains & 41 & 186 & 346 & 577 \\
Southern Great Plains & 50 & 153 & 306 & 510 \\
\hline
\end{tabular}

Source: own edition based on CSO data (2015)

Note: data in thousands

Figure 5: Your business has been involved in R\&D projects?

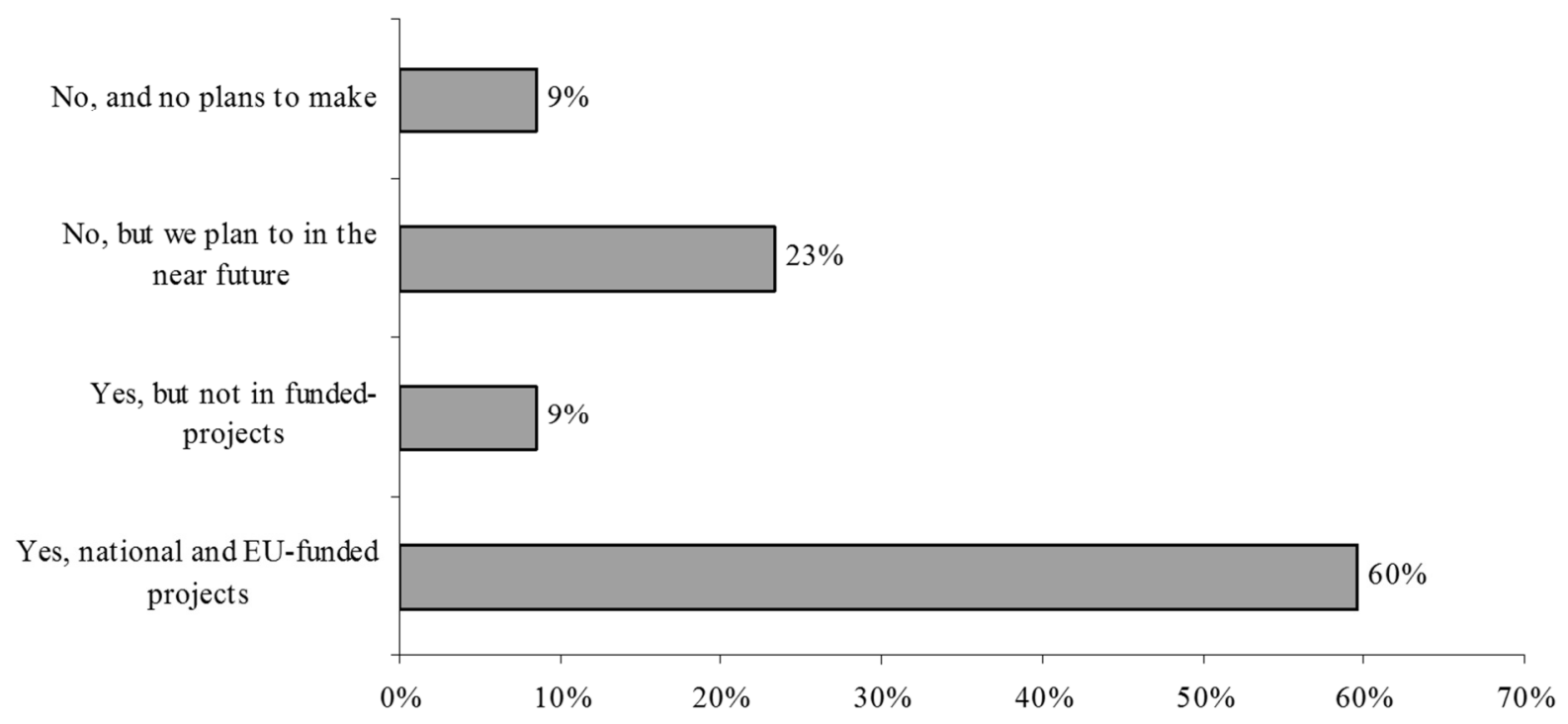

Source: based on the questionnaires edited

\section{CONCLUSIONS}

Both at European and national level the tertiary and quaternary sectors of the metropolitan regions are concentrated in the centre. In rural areas such classes can only be met in the premises which temporarily transform sectoral structure of these areas but from the regional development aspests they do not prove to be an effective strategy. On the one hand because in the long run they perpetuate the unfavourable economic structure, on the other hand, in crises situation to streamline operational processes and activities they 
tend to liquidate their rural sites in the first place. Regional development can only be effective and successful if the transformation of economic structure leads to the transformation of local social structure.

The European Commission is now focusing on growth from innovation, which could become the driving force behind productivity growth and the economy's long-term trend. The innovation-oriented economic development's key players are on one hand the knowledgeintensive enterprises, on the other hand, the universities. Tertiary education - among others - can play a part in the formation and creation of an adequate environment and system of criteria suitable for development of knowledge-intensive businesses, and can participate in developing a network of contacts which is also a prerequisite of job creation.
Based on empirical research, it can be concluded that under the influence of the European Union's cohesion and structural policy key sectors with innovation potential in the central region are looking for opportunities for cooperation with universities in the convergence region which have $R \& D$ innovation performances. In this process resource ties (development funds) dominate out of the typed network connections. The cooperation between innovative enterprises of the central region and universities in the convergence regions can result in a new type of networking. However, the community territorial cohesion policy can only be effective if - as a result of onlocking the resource limits - the spatial concentration of key sectors diminish and company headquarters are decentralised.

\section{REFERENCES}

Bajmóczy Z.-Imreh Sz.-Kosztopulosz A.-Málovics Gy.-Vas Zs. (2010): A tudás-intenzív vállalkozások müködési sajátosságai és formálódásukat befolyásoló tényezők. [In: Bajmóczy Z. (szerk.) Tudáshasznosulást, tudástranszfert szolgáló eszköz- és feltételrendszer kialakítása, fejlesztése a Szegedi Tudományegyetemen és a Dél-alföldi régióban.] Szegedi Tudományegyetem. Szeged. $5-96$.

CSO (2012): A GDP nemzetgazdasági ágak szerinti megoszlása 2011.

CSO (2014): A bruttó hozzáadott érték értéke és megoszlása nemzetgazdasági áganként (1995-) ESA2010.

CSO (2015): A foglalkoztatottak száma nemzetgazdasági ágak szerint (2014)

Deák Cs. (2001): Változás, változtatás, újjáalakítás a magyar vállalatok gyakorlatában. Gazdaságtudományi Közlemények. Miskolci Egyetem. Miskolc. 1. 2: 56.

Drejer, I.-Vindig, A. L. (2005): Location and collaboration: manufacturing firms use of knowledge intensive services in product innovation. European Planning Studies. 13. 6: 879-898.

Etzkowitz, H.-Leydesdorff, L. (2000): The Dynamics of Innovation: from National System and ,Mode 2" to a Triple Helix of UniversityIndustry-Government Relations. Research Policy. 29: 109-123.

European Union (2014): Hatodik jelentés a gazdasági, társadalmi és területi kohézióról. Az Európai Unió Kiadóhivatala. Luxemburg.

Ford, D. (2003): Business Marketing. KJK-KERSZÖV. Budapest.

Gál Z. (2014): A felsőoktatás területi szerkezetének változásai. Educatio. 23. 1: 108-120.

Häkansson, H.-Snehota, I. (1995): Developing Relationships in Business Networks. Routledge. London.

Horváth Gy. (1994): A Dél-Dunántúl nemzetközi versenyképességének előfeltétele, a technológiai megújulás. Tér és Társadalom. 8. 1-2: 37-58.
Kállay L. (2000): Mikrohitelezés piac alapon. Közgazdasági Szemle. 47. 1: 41-63.

Köpeczi-Bócz T. (2000): A szakképzés fejlesztése a foglalkoztathatóság szemszögéből. Budapesti Müszaki és Gazdaságtudományi Egyetem. Budapest.

Köpeczi-Bócz T.-Lőrincz M. (2016a): A forrásközvetítés szerepe a tudás-intenzív vállalkozások müködésében és fejlesztésében. Agrártudományi Közlemények. 69: 109-113.

Köpeczi- Bócz T.-Lörincz M. (2016b): Az innovatív vállalkozások erőforrás szükségleteinek sajátosságai. Agrártudományi Közlemények. 69: 123-127.

Lörincz M.-Köpeczi-Bócz T. (2016a): A vállalkozások székhely és tevékenységi kör szerinti differenciálása. Agrártudományi Közlemények. 67: 55-59.

Lőrincz M. - Köpeczi-Bócz T. (2016b): A felsőoktatás képzési szerkezetét és kutatás fejlesztési potenciálját befolyásoló tényezők időben és térben. Agrártudományi Közlemények. 67: 49-53.

Muller, E. (2001): Innovation interactions between knowledgeintensive business services and small-and medium-sized enterprises. An analysis in terms of evolution, knowledge and territories. Physica-Verlag. Heidelberg.

OECD (2004): Networks, Partnerships, Clusters and Intellectual Property Rights: Opportunities and Challenges for Innovative SMEs in a Global Economy. http://www.oecd.org/cfe/smes/ 31919244.pdf letöltés időpontja: 2016. március 02.

Szerb, L. (2003): The Changing Role of Enterpreneur and Entrepreneurship of Network Organisation. [In: Lengyel, I. (ed.) Knowledge Transfer, Small and Medium-sized Enterprises and Regional Development in Hungary.] JATEPress. Szeged. 81-95. 
